\title{
The World Coal Quality Inventory (WoCOI)
}

\section{The Issue}

Policymakers around the world require accurate information on coal, particularly information on coal properties and characteristics, to make informed decisions regarding the best use of indigenous resources, international import needs and export opportunities, domestic and foreign policy objectives, technology transfer opportunities, foreign investment prospects, environmental and health assessments, and byproduct use and disposal issues.

\section{The Problem}

Unfortunately, the comprehensive information needed to make these decisions generally is not available. Although millions of coal analyses have been performed worldwide, most existing national coal-quality databases are of limited use because of the following reasons:

- Many of the data are in obscure publications, commonly in the native languages of the authors or the data reside in paper files that are not readily accessible.

- Geographic coverages of a country's coal deposits are not comprehensive.

- Analytical data may not be accurate or may be incompatible with accepted analytical schemes.

- The coal samples analyzed may not be representative of an entire deposit or the samples may represent coal that was mined years to decades ago.

- Information is lacking on important trace elements, mineralogy, and modes of occurrence of the elements of environmental concern.

In summary, no single, accessible, integrated source of reliable worldwide coal-quality and related information exists.

\section{The Solution}

The U.S. Geological Survey (USGS), in conjunction with partners from other coal-producing countries, is developing an integrated electronic database with geographic information system (GIS) coverages. The database is called the World Coal Quality Inventory (WoCQI). The coal-quality parameters that will be incorporated into the database include proximate and ultimate analyses, sulfur-form data, and major-, minor-, and trace-element content analysis. These coal-quality parameters will be determined for every sample. Semiquantitative analyses of minerals, element modes of occurrence, washability, petrography, and other factors that affect technological behavior, economic byproduct recovery, and environmental impact of coal use will be conducted on selected samples.

The World Coal Quality Inventory will contain coal-quality information from samples representing important coal beds in all the major coal-producing countries, as well as in many of the smaller coal producers (see figure below). The database will emphasize information from currently mined coals. The sources of coal-quality information

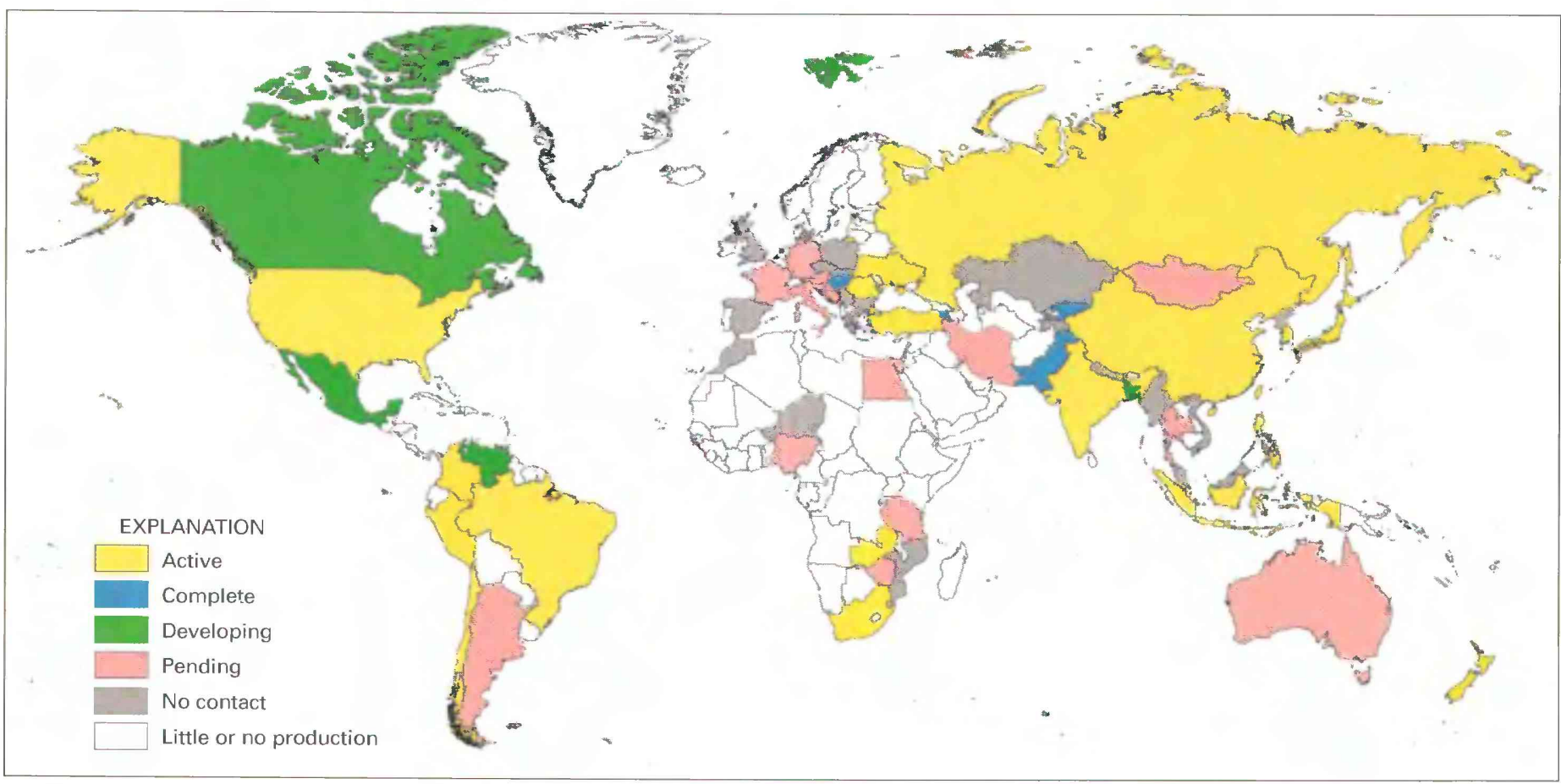

Figure 1. Status of the World Coal Quality Inventory in participating countries. 
that will be incorporated into the database include existing digital databases and credible information from publications and hardcopy files. Priority has been given to developing cooperative agreements with representatives of coal-producing countries. In most agreements. the host country is responsible for sample collection, using appropriate protocols, and the USGS is responsible for sample characterization, database development, and information dissemination. The agreements are tailored to the countries' needs and capabilities.

Coal-quality information will be linked to GIS databases to integrate geographically related information such as coal basins. sample locations. land use, transportation, environmental issues, and human health data. The World Coal Quality Inventory will be accessible from the USGS's GEO-Data Explorer (GEODE). GEODE is an interactive World Wide Web-based information-distribution system available at http://geode.usgs.gov/.

\section{The Status of Wocol}

Representatives from more than 40 coal-producing countries have agreed to participate in WoCQI. Coal samples or coal-quality information has already been obtained from more than 20 countries. For several countries, the USGS has acquired samples from every operating coal mine and even from some mine prospects. The WoCQI status in individual countries is depicted on the accompanying figure (see front page); the table (this page) provides detailed information on the status in selected countries.

Digital maps of the geology, coal basins, cultural features, epidemiology, and other other features of selected countries are being produced. The map "Coal-Bearing Regions and Structural Sedimentary Basins of China and Adjacent Seas“" (USGS Open-File Report

Table 1. Status of the World Coal Quality Inventory in selected countries.

\begin{tabular}{|c|c|}
\hline Country & Status \\
\hline Brazil & $\begin{array}{l}43 \text { samples from Rio Grande de Sul analyzed. Report in } \\
\text { preparation. }\end{array}$ \\
\hline China & $\begin{array}{l}40 \text { samples. primarily from Guizhou Province. analyzed. Agreement } \\
\text { signed to acquire about } 500 \text { additional samples. Collaboration on } \\
\text { human health impacts of residential coal use. GIS coverages } \\
\text { completed for coal basins and incidence of fluorosis. }\end{array}$ \\
\hline Colombia & $\begin{array}{l}\text { Letter of agreement signed. GIS database of coal basins nearly } \\
\text { complete. Six samples received. }\end{array}$ \\
\hline Hungary & $\begin{array}{l}39 \text { coal samples collected from all active mines. Analysis complete; } \\
\text { report in progress. }\end{array}$ \\
\hline India & $\begin{array}{l}\text { USGS developing agreement with Central Fuels Research Institute } \\
\text { and Geological Survey of India. More than } 100 \text { coal and rock samples } \\
\text { from the Sohagpur coal field in Madhya Pradesh analyzed. Eight } \\
\text { samples of high-chlorine coal from Rajasthan analyzed. GIS layers } \\
\text { completed that show coal-field boundaries, political boundaries, } \\
\text { drainage, and other features. }\end{array}$ \\
\hline Pakistan & $\begin{array}{l}\text { Approximately } 860 \text { coal samples collected and analyzed between } 1985 \\
\text { and } 1993 \text { for comprehensive coal assessment made in cooperation } \\
\text { with the U.S. Agency for International Development. Results to be } \\
\text { incorporated with new information into GIS-based summary report to } \\
\text { be available on CD-ROM and on the World Wide Web. GIS } \\
\text { coverages of coal fields and base-map data being prepared. }\end{array}$ \\
\hline Russia & $\begin{array}{l}\text { GIS coverages and coal-quality data for most major coal-producing } \\
\text { basins received. CD-ROM in preparation. Agreement to obtain more } \\
\text { coal samples being developed. }\end{array}$ \\
\hline South Korea & Samples received from all 11 operating mines. \\
\hline Turkey & $\begin{array}{l}140 \text { samples from all active lignite mines analyzed. Preliminary report } \\
\text { released. }\end{array}$ \\
\hline
\end{tabular}

OF (0)-047) has been published in CDROM and paper formats and is available through the USGS Information Services (1-888-ASK-USGS). The report is also available on the web at http://pubs.usgs.gov/openfile/of00-047/.

\section{The Future}

To ensure the most economically and environmentally efficient global use of coal, scientists must strive to develop coal-quality GIS databases that anticipate the potential uses of coalquality information. Multinational cooperation in developing a reliable. comprehensive, global coal-quality database that contains a broad array of technological, economic, and environmental parameters should help to ensure the efficient and environmentally compatible use of global coal resources in the 21 st century.

By Rohert B. Finkelman and

Vivian S. Lovern

\section{For more information, please contact:}

Robert B. Finkelman

U.S. Geological Survey

National Center, Mail Stop 956

Reston. VA 20192

Telephone: (703) 648-6412

E-mail: rbf@usgs.gov

Peter D. Warwick

U.S. Geological Survey

National Center, Mail Stop 956

Reston. VA 20192

Telephone: (703) 648-6469

E-mail: pwarwick@usgs.gov

Brenda S. Pierce

U.S. Geological Survey

National Center, Mail Stop 956

Reston, VA 20192

Telephone: (703) 648-6421

E-mail: bpierce@usgs.gov 